\title{
Subarachnoid haemorrhage with orgasmic cephalgia
}

\author{
Deepwant Singh, ${ }^{1}$ Adnan Jan ${ }^{2}$
}

1 Department of Medicine \& Rheumatology, West Suffolk Hospital NHS Foundation Trust, Bury St Edmunds, Suffolk, UK 2Department of Medicine, Warwick Hospital, South Warwickshire NHS Foundation Trust, Warwick, Warwickshire, UK

\section{Correspondence to} Dr Deepwant Singh, deepwant@doctors.org.uk

\section{DESCRIPTION}

A 40-year-old previously fit and well man presented with severe dull headache which had begun $26 \mathrm{~h}$ prior to presentation, while he was masturbating, and lasted for a min. It was associated with neck and jaw muscles' contractions. After $10 \mathrm{~min}$, he then developed a sudden severe thumping headache, at the moment of orgasm, lasting for $20 \mathrm{~s}$ suggesting a probable orgasmic headache which left him with a mild headache with reported 'neck spasm' for an hour. Thereafter, his symptoms gradually progressed in severity over the next $24 \mathrm{~h}$ untill he presented with a severe dull headache. He described these headaches as different from his migraine which is usually associated with a transient blurred vision.

Neurological and systemic examinations were unremarkable. He had normal liver/renal/bone profiles, full blood count and inflammatory markers. His clinical features were suggestive of the first presentation of a benign sexual headache without potentially discriminating factors like lack of convincing objective neck stiffness, focal neurological signs, loss of consciousness or any protracted nature of headache. However, on further direct questioning, his wife reported an ill-sustained witnessed seizure-like activity for few seconds after orgasmic headache.

Making a diagnosis of a primary headache associated with sexual activity on the first presentation requires that structural causes should be excluded ${ }^{1}$ and due to an unexplained seizure-like activity, a head CT scan was performed which demonstrated acute subarachnoid bleed within the basal cisterns, Sylvian

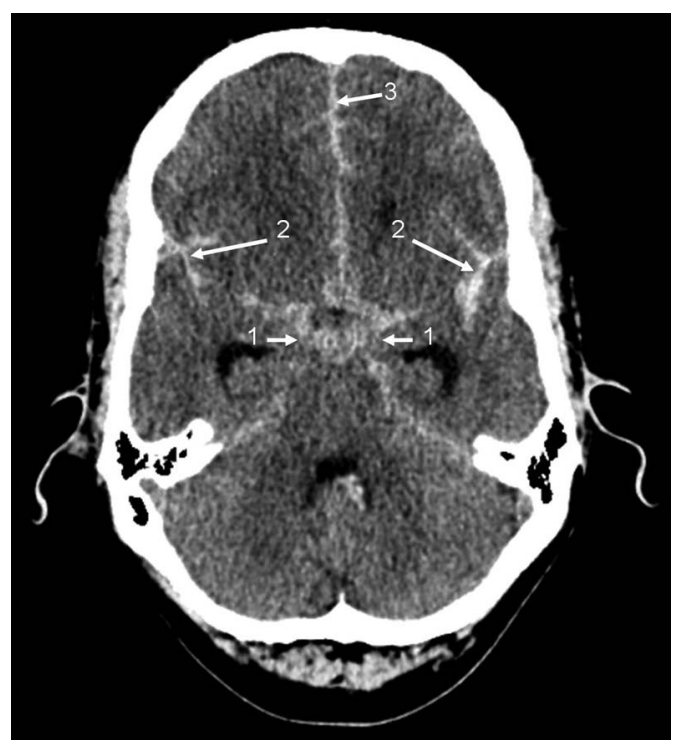

Figure 1 Axial unenhanced head CT scan view demonstrates high attenuation material within the basal cisterns (arrow 1), Sylvian fissures (arrow 2) and alongside the falx (arrow 3), consistent with subarachnoid haemorrhage.

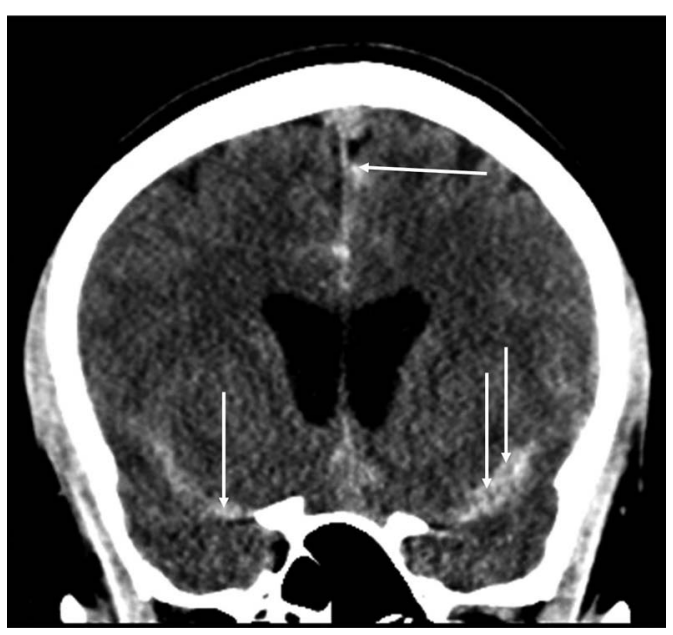

Figure 2 Coronal unenhanced head CT scan view showed blood along falx cerebri and slightly more blood on the left side than right around middle cerebral artery (MCA) area (see arrows) raising suspicion of probable left MCA aneurysm as a source of haemorrhage.

fissures extending over left cerebral convexities and alongside the falx (figures 1 and 2). Subsequently, the patient had CT angiogram which confirmed an anterior-communicating artery aneurysm rupture treated by endovascular occlusion of aneurysm by coil embolisation. He was then discharged 10 days later with no residual focal neurological deficit.

An orgasmic headache could be particularly worrisome because $4-12 \%$ of patients presenting with subarachnoid haemorrhage due to aneurismal rupture cite sexual activity as the precipitating event. $^{23}$ This case reiterates that in patients with a new onset or never-evaluated first presentation of headache with sexual activity; clinicians should remember the vital role of performing neuroimaging (CT/MRI scan of the head) to exclude an underlying potential intracerebral haemorrhage.

\section{Learning points}

- Headache associated with sexual activity may represent a benign primary disorder but it may be a warning symptom of an underlying potential sub-arachnoid haemorrhage.

- Patients presenting with the first presentation of a new onset or never-evaluated orgasmic headache should have neuroimaging (head CT/ MRI scan) to exclude intracranial haemorrhage.

Contributors AJ assessed the patient in an emergency assessment unit and requested investigations based on high clinical suspicion. DS wrote the case report and filed the images for the publication. 


\section{Images in...}

Competing interests None.

Patient consent Obtained.

Provenance and peer review Not commissioned; externally peer reviewed.

\section{REFERENCES}

1 Silbert P, Edis R, Stewart-Wynne E, et al. Benign vascular sexual headache and exertional headache: interrelationships and long term prognosis. I Neurol Neurosurg Psychiatry 1991;54:417.
2 Lundberg P, Osterman P. The benign and malignant forms of orgasmic cephalgia. Headache 1974;14:164.

3 Locksley HB. Natural history of subarachnoid hemorrhage, intracranial aneurysms and arteriovenous malformations. Based on 6368 cases in the cooperative study. J Neurosurg 1966;25:219.

Copyright 2013 BMJ Publishing Group. All rights reserved. For permission to reuse any of this content visit http://group.bmj.com/group/rights-licensing/permissions.

BMJ Case Report Fellows may re-use this article for personal use and teaching without any further permission.

Become a Fellow of BMJ Case Reports today and you can:

- Submit as many cases as you like

- Enjoy fast sympathetic peer review and rapid publication of accepted articles

- Access all the published articles

- Re-use any of the published material for personal use and teaching without further permission

For information on Institutional Fellowships contact consortiasales@bmjgroup.com

Visit casereports.bmj.com for more articles like this and to become a Fellow 